CENDEKIA, Vol. 11, No. 2, Oktober 2017

p ISSN: 1978 2098; e ISSN: 2407 8557

Http://cendekia.pusatbahasa.or.id; Email: cendekiaoslo@gmail.com

Center of Language and Culture Studies, Surakarta, Indonesia

Suprapti, Sri. 2017. Meningkatkan Hasil Belajar Membaca Legenda Melalui

Model Number Heads Together Siswa SMPN 8 Surakarta.

Cendekia, (2017), 11(2): 221 234.

\title{
MENINGKATKAN HASIL BELAJAR MEMBACA LEGENDA MELALUI MODEL NUMBERED HEADS TOGETHER SISWA SMPN 8 SURAKARTA
}

\author{
Sri Suprapti \\ SMP Negeri 8 Surakarta \\ Email: suprapti305@yahoo.com
}

\begin{abstract}
Abstrct: The purpose of this study to enhance the activity and achievement in the Javanese language for the reading material of legend using cooperative learning methods Numbered Heads Together (NHT). This study used a twocycle classroom action research. Subjects in this study were 32 students of class VIII E SMPN 8 Surakarta in the 2015/2016 school year, consisiting of 18 girls and 14 boys. The research was conducted in two cycles. Each cycle has four phases: planning, implementation, observation and reflection. In the first cycle the researcher used NHT without media and in Cycle II, NHT was used with instructional media. Results of the study showed increased percentage of the motivation to learn the Javanese language to read the Legend. Description of the achievement included: listening and attention to the teacher's explanations was $34.38 \%$; couragement to ask and express opinions was $31.25 \%$; and the couragement to present results of group discussions in class was $59.38 \%$.
\end{abstract}

Keywords: legend, Numbered Heads Together, reading content.

Masyarakat Jawa pada umumnya dan khususnya para keluarga muda dewasa ini semakin kurang menguasai terhadap bahasa Jawa, sebagai dampaknya dalam mendidik dan berkomunikasi dengan anak kandung sendiri tidak mau menggunakan bahasa Jawa, cenderung memilih bahasa lain. Bahkan sering terjadi apabila anaknya mendapat PR pelajaran bahasa Jawa, dan anak bertanya kepada orang tuanya, kedua orang tua tersebut tidak bisa menjawab. Sehingga sangatlah ironis bila dikatakan orang Jawa tetapi tidak mengerti terhadap bahasanya sendiri. Maka banyak sesepuh yang mengatakan bahwa sekarang ini, wong Jawa ilang Jawane lan kapribadene (orang Jawa yang kehilangan perilaku dan kepribadiannya). Terlepas dari kejanggalan tersebut di atas, kita pantas bersyukur, berbangga dan bergembira karena mulai tahun pelajaran 2005/2006 semua jenjang sekolah di propinsi Jawa Tengah baik negeri maupun swasta wajib memberikan mata pelajaran bahasa Jawa.

Ruang lingkup mata pelajaran Bahasa Jawa mencakup komponen keterampilan berbahasa dan bersastra. Keterampilan berbahasa meliputi aspek-aspek mendengarkan atau menyimak, membaca, berbicara dan menulis. Mendengarkan dan membaca merupakan aspek kebahasaan yang bersifat pasif dan reseptif (penerimaan), sedangkan berbicara dan menulis keterampilan berbahasa yang bersifat aktif dan produktif. Model pembelajaran yang telah berlangsung selama ini ternyata belum memberi kontribusi yang baik untuk peningkatan hasil belajar Bahasa Jawa dengan model yang kurang 
CENDEKIA, Vol. 11, No. 2, Oktober 2017

p ISSN: 1978 2098; e ISSN: 2407 8557

Http://cendekia.pusatbahasa.or.id; Email: cendekiaoslo@gmail.com

Center of Language and Culture Studies, Surakarta, Indonesia

Suprapti, Sri. 2017. Meningkatkan Hasil Belajar Membaca Legenda Melalui

Model Number Heads Together Siswa SMPN 8 Surakarta.

Cendekia, (2017), 11(2): 221 234.

kooperatif terhadap siswa maka aktifitas belajar dan hasil belajar Bahasa Jawa masih rendah.

Berdasarkan realita tersebut maka penulis menggunakan metode pembelajaran kooperatif Tipe Numbered Heads Together (NHT) diharapkan aktifitas dan hasil belajar siswa pada kompetensi mendengarkan legenda lebih meningkat dan mengapa harus menggunakan model pembelajaran kooperatif tipe NHT?. Karena tipe ini mempunyai kelebihan yaitu terjadinya interaksi antara siswa melalui diskusi/siswa secara bersama dalam menyelesaikan masalah yang dihadapi. Siswa pandai maupun siswa lemah sama-sama memperoleh manfaat melalui aktifitas belajar kooperatif. Dengan bekerja secara kooperatif ini, kemungkinan konstruksi pengetahuan akan menjadi lebih besar/ kemungkinan untuk siswa dapat sampai pada kesimpulan yang diharapkan. Selain itu juga dapat memberikan kesempatan kepada siswa untuk menggunakan keterampilan bertanya, berdiskusi dan mengembangkan bakat kepemimpinan. Walaupun Tipe NHT ini juga ada kelemahannya tetapi masih banyak kelebihan yang diharapkan.

Dari permasalahan yang telah diuraikan serta kesesuaian model pembelajaran kooperatif tipe NHT dalam meningkatkan aktifitas belajar siswa, maka peneliti akan berkolaborasi dengan guru untuk berusaha mengatasi permasalahan tersebut yaitu, untuk meningkatkan aktifitas belajar Bahasa Jawa di kelas tersebut dengan melakukan suatu penelitian tindakan kelas di kelas VIII E SMP Negeri 8 Surakarta dengan menerapkan model pempelajaran kooperatif NHT pada siklus I tanpa media dan pada siklus II dengan menggunakan media .

Berdasarkan latar belakang masalah di atas dapat diidentifikasikan yaitu bagaimana upaya guru untuk meningkatkan aktifitas dan hasil belajar bagi peserta didik kelas VIII E SMP Negeri 8 Surakarta Tahun Pelajaran 2015/2016?

Masalah yang akan diteliti meliputi dua variable tindakan adalah: Aktifitas belajar peserta didik, yang ingin ditingkatkan meliputi: a. Mendengarkan dan memperhatikan penjelasan guru. b. Keberanian bertanya dan mengemukakan pendapat.c. Keberanian mempresentasikan hasil diskusi kelompok di depan kelas. Model pembelajaran yang digunakan adalah model pembelajaran kooperatif tipe NHT, secara kelompok kecil terdiri dari 4-5 melalui tahap perencanaan, pelaksanaan tindakan, observasi dan interpretasi, analisa dan refleksi pada siklus I maupun siklus II.

Perumusan masalah sebagai berikut: Apakah melalui penerapan model NHT dapat meningkatkan aktifitas dan hasil belajar Bahasa Jawa kompetensi membaca Legenda melalui penerapan model pembelajaran kooperatif tipe NHT bagi peserta didik kelas VIII E semester 1 SMP Negeri 8 Surakarta Tahun Pelajaran 2015/2016?.

Tujuan Penelitian ini adalah untuk meningkatkan aktifitas dan hasil belajar melalui penerapan model NHT dapat meningkatkan aktifitas dan hasil belajar Bahasa Jawa kompetensi membaca Legenda melalui penerapan model pembelajaran kooperatif tipe NHT bagi peserta didik kelas VIII E semester 1 SMP Negeri 8 Surakarta Tahun Pelajaran 2015 / 2016.

Manfaat dari penelitian tindakan kelas ini melalui penerapan model NHT dapat meningkatkan aktifitas dan hasil belajar Bahasa Jawa kompetensi Membaca Legenda 
CENDEKIA, Vol. 11, No. 2, Oktober 2017

p ISSN: 1978 2098; e ISSN: 2407 8557

Http://cendekia.pusatbahasa.or.id; Email: cendekiaoslo@gmail.com

Center of Language and Culture Studies, Surakarta, Indonesia

Suprapti, Sri. 2017. Meningkatkan Hasil Belajar Membaca Legenda Melalui

Model Number Heads Together Siswa SMPN 8 Surakarta.

Cendekia, (2017), 11(2): 221 234.

melalui penerapan model pembelajaran kooperatif tipe NHT bagi peserta didik kelas VIII E semester 1 SMP Negeri 8 Surakarta tahun 2015/2016 , diharapkan dapat bermanfaat a ) Bagi siswa untuk meningkatkan aktifitas dan hasil belajar Bahasa Jawa kompetensi Mendengarkan Legenda melalui penerapan model pembelajaran kooperatif tipe NHT bagi peserta didik kelas VIII E semester 1 SMP Negeri 8 Surakarta Tahun Pelajaran 2015/2016. b) Bagi Guru untuk meningkatkan aktifitas dan hasil belajar Bahasa Jawa kompetensi membaca legenda melalui model pembelajaran tipe NHT bagi peserta didik kelas VIII E SMP Negeri 8 Surakarta Tahun Pelajaran 2015/2016. c) Bagi Sekolah hasil penelitian ini dapat dijadikan acuan dalam melakukan inovasi pembelajaran keterampilan bahasa bagi guru bahasa Jawa dan memotivasi untuk selalu melakukan inovasi dengan strategi yang lain. d) Bagi peneliti untuk menambah wawasan tentang pelaksanaan pembelajaran sastra, khususnya legenda. Kelebihan dan kelemahannya, serta mengetahui kondisi saat ini yang terjadi dalam proses pembelajaran sastra di dalam kelas.

\section{Pengertian Aktifitas Belajar Bahasa Jawa}

Kata aktifitas berasa dari kata activity yang artinya kegiatan. Belajar yang berhasil mesti melalui berbagai macam aktifitas, baik aktifitas fisik maupun psikis. Belajar adalah berbuat untuk mengubah tingkah laku atau melakukan suatu kegiatan. Tidak ada belajar kalau tidak ada aktifitas, sehingga suatu pembelajaran akan lebih efektif jika dalam pembelajaran tersebut menyediakan kesempatan kepada siswa untuk belajar sendiri atau melakukan aktifitas sendiri.

Soemanto (2006:107-113), mengemukakan beberapa aktifitas belajar dalam beberapa situasi sebagai berikut: mendengarkan, memandang, meraba, mencium dan mencicipi/mengecap, menulis dan mencatat, membaca,membuat ikhtisar atau ringkasan, dan menggarisbawahi, mengamati tabel-tabel, diagram-diagram dan bagan-bagan, menyusun paper atau kertas kerja, mengingat berfikir, latihan atau praktek. Menurut Mulyono (2001:26), aktifitas artinya "kegiatan atau keaktifan". Jadi segala sesuatu yang dilakukan atau kegiatan-kegiatan yang terjadi baik fisik maupun non fisik, merupakan suatu aktifitas.

Menurut Sriyono (Rosalia, 2005:2), aktifitas adalah segala kegiatan yang dilaksanakan baik secara jasmani atau rohani. Aktifitas siswa selama proses belajar mengajar merupakan salahsatu indikator adanya keinginana siswa untuk belajar. Aktifitas siswa merupakan kegiatan atau perilaku yang terjadi selama proses belajar mengajar. Kegiatan-kegiatan yang dimaksud adalah kegiatan yang mengarah pada proses belajar seperti bertanya, mengajukan pendapat, mengerjakan tugas-tugas, dapat menjawab pertanyaan guru dan bisa bekerja sama dengan siswa lain, serta tanggungjawab terhadap tugas yang diberikan.

Aktifitas belajar merupakan keaktifan siswa dalam proses pembelajaran akan menyebabkan interaksi yang tinggi antara guru dengan siswa ataupun dengan siswa itu sendiri. Hal ini akan mengakibatkan suasana kelas menjadi segar dan kondusif, dimana masing-masing siswa dapat melibatkan kemampuannya semaksimal mungkin. Aktifitas 
CENDEKIA, Vol. 11, No. 2, Oktober 2017

p ISSN: 1978 2098; e ISSN: 2407 8557

Http://cendekia.pusatbahasa.or.id; Email: cendekiaoslo@gmail.com

Center of Language and Culture Studies, Surakarta, Indonesia

Suprapti, Sri. 2017. Meningkatkan Hasil Belajar Membaca Legenda Melalui

Model Number Heads Together Siswa SMPN 8 Surakarta.

Cendekia, (2017), 11(2): 221 234.

yang timbul dari siswa akan mengakibatkan pula terbentuknya pengetahuan dan keterampilan yang akan mengarah pada peningkatan prestasi.

Aktifitas belajar merupakan suatu kegiatan yang dilakukan untuk menghasilkan perubahan pengetahuan-pengetahuan, nilai-nilai sikap dan keterampilan pada siswa sebagai latihan yang dilaksanakan secara sengaja. Seperti yang dikemukakan oleh Rochman Natawijaya dalam Depdiknas (2005:31), belajar aktif adalah "suatu sistem belajar mengajar yang menekankan keaktifan siswa secara fisik, mental intelektual dan emosional guna memperoleh hasil belajar berupa perpaduan antara aspek kognitif, afektif dan psikomotor".

Menurut Sardiman (2007:102) dalam Tri Unggul (2013:35), aktifitas belajar siswa yang akan diamati meliputi: 1) Aktifitas Melihat dan Mendengar, meliputi: mendengarkan dan memperhatikan penjelasan guru. 2) Aktivasi Lisan: Keberanian bertanya dan mengemukakan pendapat. 3) Aktifitas Menulis: Mencatat penjelasan guru.

Jadi berdasarkan pendapat ahli dapat disimpulkan bahwa aktifitas belajar merupakan segala kegiatan yang dilakukan dalam proses interaksi (guru dan siswa) dalam rangka mencapai tujuan belajar. Aktifitas yang dimaksudkan di sini penekanannya adalah pada siswa, sebab dengan adanya aktifitas siswa dalam proses pembelajaran terciptalah situasi belajar aktif.

\section{Hakikat Bahasa Jawa}

Hakikat Bahasa adalah sebuah sistem lambang: berupa tanda-tanda, seperti rambu-rambu lalu lintas, gambar atau petunjuk, dan dapat juga berupa gerak-gerik anggota badan (kinesik).

Belajar adalah perubahan yang relatif permanen dalam perilaku atau potensi perilaku sebagai hasil dari pengalaman atau latihan yang diperkuat. Belajar merupakan akibat adanya interaksi antara stimulus dan respon. Seseorang dianggap telah belajar sesuatu jika dia dapat menunjukkan perubahan perilakunya. Menurut teori ini dalam belajar yang penting adalah input yang berupa stimulus dan output yang berupa respon. Stimulus adalah apa saja yang diberikan guru kepada pelajar, sedangkan respon berupa reaksi atau tanggapan pelajar terhadap stimulus yang diberikan oleh guru tersebut. Menurut Winkel, belajar adalah semua aktifitas atau psikis yang berlangsung dalam interaksi aktif dalam lingkungan yang menghasilkan perubahan- perubahan dalam pengelolaan pemahaman. Menurut Hilgard dalam (Suryabrata, 1984:252) Belajar merupakan proses perbuatan yang dilakukan dengan sengaja, yang kemudian menimbulkan perubahan, yang keadaannya berbeda dari perubahan yang ditimbulkan oleh lainnya.

Dari beberapa pengertian belajar di atas maka dapat disimpulkan bahwa pada prinsipnya belajar adalah perubahan dari diri seseorang. Atau dengan kata lain bahwa semua aktifitas mental atau psikis yang dilakuakn oleh seseorang sehingga menimbulkan perubahan tingkah laku yang berbeda antara sesudah belajar dan sebelum belajar. 
CENDEKIA, Vol. 11, No. 2, Oktober 2017

p ISSN: 1978 2098; e ISSN: 2407 8557

Http://cendekia.pusatbahasa.or.id; Email: cendekiaoslo@gmail.com

Center of Language and Culture Studies, Surakarta, Indonesia

Suprapti, Sri. 2017. Meningkatkan Hasil Belajar Membaca Legenda Melalui

Model Number Heads Together Siswa SMPN 8 Surakarta.

Cendekia, (2017), 11(2): 221 234.

\section{Hasil Belajar}

Dalam Dimyati dan Mudjiono (2006) hasil belajar adalah hasil yang dicapai dalam bentuk angka-angka atau skor setelah diberikan tes hasil belajar pada setiap akhir pembelajaran. Nilai yang diperoleh siswa menjadi acuan untuk melihat penguasaan siswa dalam menerima materi pelajaran.

Hamalik (2008) hasil belajar adalah sebagai terjadinya perubahan tingkah laku pada diri seseorang yang dapat di amati dan di ukur bentuk pengetahuan, sikap dan ketrampilan. Perubahan tersebut dapat di artikan sebagai terjadinya peningkatan dan pengembangan yang lebih baik sebelumnya yang tidak tahu menjadi tahu.

Jadi yang dimaksud hasil belajar dalam penelitian ini adalah prestasi belajar yang dicapai siswa dalam proses kegiatan belajar mengajar yang dicapai siswa dalam proses kegiatan belajar mengajar dengan membawa suatu perubahan dan pembentukan tingkah laku seseorang. Untuk menyatakan bahwa suatu proses belajar dapat dikatakan berhasil, setiap guru memiliki pandangan masing-masing sejalan dengan filsafatnya. Namun unguk menyamakan persepsi sebaiknya kita berpedoman pada kurikulum yang berlaku saat ini yang telah disempurnakan, antara lain bahwa suatu proses belajar mengajar tentang suatu bahan pembelajaran dinyatakan berhasil apabila tujuan pembelajaran khususnya dapat dicapai.

\section{Hasil Belajar Bahasa Jawa Pada Kompetensi Membaca Legenda}

Hasil belajar bahasa Jawa adalah sesuatu hasil nyata yang dicapa dalam belajar bahasa Jawa oleh siswa dalam usaha menguasai kecakapan jasmani dan rohani di sekolah yang diwujudkan dalam bentuk raport pada setiap semester. Untuk mengetahui perkembangan sampai di mana hasil yang telah dicapai oleh seseorang dalam belajar bahasa Jawa, maka harus dilakukan evaluasi. Untuk menentukan kemajuan yang dicapai maka harus ada kriteria (patokan) yang mengacu pada tujuan yang telah ditentukan sehingga dapat diketahui seberapa besar pengaruh strategi belajar mengajar bahasa Jawa terhadap keberhasilan siswa.

Hasil belajar siswa menurut Winkel (1989:82) adalah keberhasilan yang dicapai oleh siswa yakni prestasi belajar siswa di sekolah yang mewujudkan dalam bentuk angka. Menurut Surakhmad (1980:25) hasil belajara siswa bagi kebanyakan orang berarti ulangan, ujian atau tes. Maksud ulangan tersebut ialah untuk memperoleh suati indek dalam menentukan keberhasilan siswa.

Untuk mengetahui tercapai tidaknya tujuan pembelajaran khusus, guru perlu mengadakan tes formatif pada setiap menyajikan suatu bahasan kepada siswa. Penilaian formatif ini untuk mengetahui sejauh mana siswa telah menguasai tujuan pembelajaran khusus yang ingin dicapai. Fungsi penelitian ini adalah untuk memberikan umpan balik pada guru dalam rangka memperbaiki proses belajar mengajar bahasa Jawa dan melaksanakan program remedial bagi siswa yang belum berhasil. Oleh karena itulah, suatu proses belajar mengajar bahasa Jawa dinyatakan berhasil apabila memenuhi tujuan pembelajaran khusus dari berbicara legenda. Indikator hasil belajar siswa adalah sebagai berikut: 
CENDEKIA, Vol. 11, No. 2, Oktober 2017

p ISSN: 1978 2098; e ISSN: 2407 8557

Http://cendekia.pusatbahasa.or.id; Email: cendekiaoslo@gmail.com

Center of Language and Culture Studies, Surakarta, Indonesia

Suprapti, Sri. 2017. Meningkatkan Hasil Belajar Membaca Legenda Melalui

Model Number Heads Together Siswa SMPN 8 Surakarta.

Cendekia, (2017), 11(2): 221 234.

a. Ketercapaian daya serap terhadap bahan pembelajaran yang diajarkan baik secara individual maupun kelompok. Pengukuran ketercapaian daya serap ini biasanya dilakukan dengan penetapan Kriteria Ketuntasan Belajar Minimal (KKM).

b. Perilaku yang digariskan dalam tujuan pembelajaran yang telah dicapai oleh siswa, baik secara individual maupun kelompok. Namun demikian indikator yang banyak dipakai sebagai tolak ukur keberhasilan adalah daya serap.

\section{Penilaian Hasil Belajar}

Mengukur dan mengevaluasi hasil belajar siswa tersebut dapat dilakukan melalui tes prestasi belajar. Berdasarkan tujuan dan ruang lingkupnya, tes prestasi belajar dapat digongkan ke dalam jenis penilaian, sebagi berikut:

a. Tes formatif, penilaian ini dapat mengukur satu atau beberapa pokok bahasa tertentu dan tujuannya untuk memperoleh gambaran tentang daya serap siswa terhadap pokok bahasan tersebut. Hasil tes ini dimanfaatkan untuk memperbaiki proses belajar mengajar dalam waktu tertentu.

b. Tes Subsumatif, tes ini meliputi sejumlah bahan pengajaran tertentu yang telah diajarkan dalam waktu tertentu. Tujuannya adalah untuk memperoleh gambaran daya serap siswa untuk meningkatkan tingkat prestasi belajar atau hasil belajar siswa. Hasil tes subsumatif ini dimanfaatkan untuk memperbaiki proses belajar mengajar dan diperhitungkan dalam menentukan nilai raport.

c. Tes sumatif, tes ini diadakan untuk mengukur daya serap siswa terhadap bahan pokok-pokok bahasan yang telah diajarkan selama satu semester, satu atau dua bahan pelajaran. Tujuannya adalah untuk menetapkan tarap atau tingkat keberhasilan belajar siswa dalam satu periode belajar tertentu. Hasil dari tes sumatif ini dimanfaatkan untuk kenaikan kelas, menyusun peringkat (rangking) atau sebagai ukuran mutu sekolah.

\section{Model Pembelajaran NHT}

Pembelajaran kooperatif tipe NHT merupakan salah satu tipe pembelajaran kooperatif yang menekankan pada struktur khusus yang dirancang untuk mempengaruhi pola interaksi siswa dan memiliki tujuan untuk meningkatkan penguasaan akademik. Langkah-langkah tersebut kemudian dikembangkan oleh Ibrahim (2000:29) menjadi enam langkah sebagai berikut:

\section{Langkah 1: Persiapan}

Dalam tahap ini guru mempersiapkan rancangan pelajaran dengan membuat Skenario Pembelajaran (SP), Lembar kerja Siswa (LKS) yang sesuai dengan model pembelajaran kooperatif tipe NHT.

Langkah 2: Pembentukan kelompok

Dalam pembentukan kelompok disesuaikan dengan model pembelajaran kooperatif tipe NHT. Guru membagi para siswa menjadi beberapa kelompok yang beranggaotakan 3-5 anak. Guru memberi nomor kepada setiap siswa dalam kelompok dan nama 
CENDEKIA, Vol. 11, No. 2, Oktober 2017

p ISSN: 1978 2098; e ISSN: 2407 8557

Http://cendekia.pusatbahasa.or.id; Email: cendekiaoslo@gmail.com

Center of Language and Culture Studies, Surakarta, Indonesia

Suprapti, Sri. 2017. Meningkatkan Hasil Belajar Membaca Legenda Melalui

Model Number Heads Together Siswa SMPN 8 Surakarta.

Cendekia, (2017), 11(2): 221 234.

kelompok yang berbeda. Kelompok yang dibentuk merupakan percampuran yang ditinjau dari latar belakang sosial, ras, suku, jenis kelamin dan kemampuan belajar. Selain itu, dalam pembentukan kelompok digunakan nilai tes awal (pre-test) sebagai dasar dalam menentukan masing-masing kelompok.

Langkah 3: Tiap kelompok harus memiliki buku paket atau buku panduan

Dalam pembentukan kelompok harus memiliki buku paket atau buku panduan agar memudahkan siswa dalam penyelesaian LKS atau masalah yang diberikan oleh guru.

Langkah 4: Diskusi masalah

Guru membagikan LKS kepada setiap siswa sebagai bahan yang akan dipelajari. Dalam kerja kelompok setiap siswa berpikir bersama untuk menggambarkan dan meyakinkan bahwa tiap orang mengathui jawaban dari pertanyaan yang telah ada dalam LKS atau pertanyaan yang telah diberikan oleh guru. Pertanyaan dapat bervariasi, dari yang bersifat spesifik sampai yang bersifat umum.

Langkah 5: Memanggil nomor anggota atau pemberian jawaban

Dalam tahap ini, guru menyebut satu nomor dan para siswa dari tiap kelompok dengan nomor yang sama mengangkat tangan dan menyiapkan jawaban kepada siswa di kelas.

Langkah 6: Memberi kesimpulan

Guru bersama siswa menyimpulkan jawaban akhir dari semua pertanyaan yang berhubungan dengan materi yang disajikan.

Ada beberapa manfaat pada model pembelajaran kooperatif tipe NHT, terhadap siswa yang hasil belajar rendah yang dikemukakan oleh Lundgren dalam Ibrahim (2000:18), antara lain adalah: Rasa harga diri menjadi lebih tinggi, Memperbaiki kehadiran, Penerimaan terhadap individu menjadi lebih kecil, Konflik antar pribadi berkurang, Pemahaman yang lebih mendalam, Perilaku mengganggu menjadi lebih kecil, Meningkatkan kebaikan budi, kepekaan dan toleransi, hasil belajar lebih tinggi.

Bahasa memiliki peran sentral dalam perkembangan intelektual, sosial dan emosional siswa serta menunjang keberhasilan dalam mempelajari semua bidang studi. Pembelajaran bahasa diharapkan membantu siswa mengenal dirinya, budayanya dan budaya orang lain, mengemukakan gagasan dan perasaan, berpartisipasi dalam masyarakat yang menggunakan bahasa tersebut dan menemukan serta menggunakan keterampilan analitis dan imajinatif yang ada dalam dirinya. Pembelajaran bahasa Jawa diarahkan untuk meningkatkan keterampilan siswa dalam berkomunikasi menggunakan bahasa Jawa yang benar, baik secara lisan maupun tulisan, serta menumbuhkan apresiasi terhadap karya sastra.

Siswa pada tahap berikutnya diharapkan dapat menggunakan bahsa dengan efektif sesuai unggah-ungguh dan etika yang berlaku secara tepat dan kreatif untuk berbagai tujuan. Ruang lingkup mata pelajaran Bahasa Jawa mencakup komponen 
CENDEKIA, Vol. 11, No. 2, Oktober 2017

p ISSN: 1978 2098; e ISSN: 2407 8557

Http://cendekia.pusatbahasa.or.id; Email: cendekiaoslo@gmail.com

Center of Language and Culture Studies, Surakarta, Indonesia

Suprapti, Sri. 2017. Meningkatkan Hasil Belajar Membaca Legenda Melalui

Model Number Heads Together Siswa SMPN 8 Surakarta.

Cendekia, (2017), 11(2): 221 234.

keterampilan berbahasa dan bersastra. Keterampilan berbahasa meliputi aspek-aspek mendengarkan atau menyimak, membaca, berbicara dan menulis. Mendengarkan dan membaca merupakan aspek kebahasaan yang bersifat pasif dan reseptif (penerimaan), sedangkan berbicara dan menulis sebagai keterampilan berbahsa yang bersifat aktif dan produktif.

Untuk meningkatkan aktifitas dan hasil belajar Bahasa Jawa siswa di kelas VIII E, peneliti akan menerapkan model pembelajaran kooperatif tipe NHT. Pada kondisi awal, guru dalam melaksanakan proses pembelajaran belum menggunakan media akibatnya aktifitas dan hasil belajar siswa pada kompetensi membaca legenda siswa di kelas VIII E masih kurang. Jika dari tindakan siklus I dirasa masih perlu perbaikan maka dilanjutkan tindakan siklus II sehingga dapat meningkatkan aktifitas dan hasil belajar bahasa jawa bagi siswa.

Dari permasalahan yang telah diuraikan serta kesesuaian model pembelajaran kooperatif tipe NHT dalam meningkatkan aktifitas belajar siswa, maka peneliti akan berkolaborasi dengan guru untuk berusaha mengatasi permasalahan tersebut yaitu, untuk meningkatkan aktifitas belajar Bahasa Jawa di kelas tersebut dengan melakukan suatu penelitian tindakan kelas di kelas VIII E SMP Negeri 8 Surakarta dengan menerapkan model pempelajaran kooperatif NHT pada siklus I tanpa media dan pada siklus II dengan menggunakan media yaitu berupa gambar legenda dengan ceritanya.

\section{METODE}

Penelitian tindakan kelas ini akan dilaksanakan di SMP Negeri 8 Surakarta beralamat di Jl. HOS. Cokroaminoto No. 51 Surakarta. Waktu Penelitian Tindakan Kelas ini dilaksanakan selama 3 bulan yaitu pada bulan Juli sampai dengan bulan September 2015. Subjek dalam penelitian tindakan kelas ini adalah siswa kelas VIII E SMP Negeri 8 Surakarta tahun 2015 berjumlah 32 orang terdiri dari 18 perempuan dan 14 laki-laki. Data yang dikumpulkan dan dikaji dalam penelitian ini adalah data kualitatif, sumber data tersebut yaitu meliputi: Sumber data primer, yaitu siswa, guru dan sumber data sekunder yaitu dokumen, tes hasil belajar, lembar observasi, kegiatan bermain peran.

\section{Hipotesis Tindakan}

Berdasarkan pada kajian, kerangka berpikir dan kenyataan di atas, maka dapat dirumuskan hipotesis penelitian tindakan kelas ini sebagai berikut: Bahwa melalui penerapan model NHT dapat meningkatkan aktifitas dan hasil belajar Bahasa Jawa kompetensi Membaca Legenda melalui penerapan model pembelajaran kooperatif tipe NHT bagi siswa kelas VIII E semester 1 SMP Negeri 8 Surakarta Tahun Pelajaran 2015/2016.

\section{Teknik Pengumpulan Data}

Data aktifitas belajar pada kondisi awal: Data aktifitas belajar menggunakan dokumentasi yang alatnya berupa dokumen buku catatan sebelum tindakan siklus. Data hasil belajar pada kondisi awal; Data hasil belajar dengan menggunakan dokumentasi 
CENDEKIA, Vol. 11, No. 2, Oktober 2017

p ISSN: 1978 2098; e ISSN: 2407 8557

Http://cendekia.pusatbahasa.or.id; Email: cendekiaoslo@gmail.com

Center of Language and Culture Studies, Surakarta, Indonesia

Suprapti, Sri. 2017. Meningkatkan Hasil Belajar Membaca Legenda Melalui

Model Number Heads Together Siswa SMPN 8 Surakarta.

Cendekia, (2017), 11(2): 221 234.

yang alatnya berupa buku nilai, ulangan harian sebelum dilakukan tindakan. Data aktifitas belajar pada siklus I dan siklus II; Data aktifitas belajar dikumpulkan alatnya berupa lembar pengamatan tentang aktifitas selama pelaksanaan siklus I dan siklus II berlangsung. Data hasil belajar Bahasa Jawa pada siklus I dan siklus II ; Data hasil belajar Bahasa Jawa dikumpulkan menggunakan alat berupa lembar jawab dari butir soal tes tertulis bentuk tes pilihan ganda dengan empat pilihan jawaban, setelah selesai pelaksanaan tindakan setiap siklus selama melaksanakan siklus I dan siklus II.

\section{Prosedur Penelitian}

Penelitian ini merupakan penelitian tindakan kelas (classroom action research) yang ditandai dengan adanya siklus. Penelitian ini terdiri atas dua siklus. Siklus pelaksanaan Penelitian Tindakan Kelas (PTK) dilakukan melalui beberapa tahap, yaitu: Tahap Perencanaan, tahap Pelaksanaan Tindakan, Observasi dan Interpretasi, Analisa dan Refleksi.

a. Perencanaan terdiri atas kegiatan: (1) Penyusunan rencana pelaksanaan pembelajaran (RPP); (2) Penyiapan skenario pembelajaran, (3) Menyusun perangkat observasi untuk merekam segala kegiatan dalam proses pembelajaran, (4) Membuat perangkat penilaian dengan menerapkan sistem penilaian berbasis kelas.

b. Pelaksanaan terdiri atas kegiatan:

1) Siswa mengindentifikasi masalah yang dihadapi dalam berbicara legenda.

2) Siswa mengindentifikasi masalah yang dihadapi dalam proses pembelajaran khususnya dalam pelaksanaan sistem penilaian yang dilakukan oleh guru.

3) Guru mendengarkan keluhan atau permasalahan yang dihadapi siswa dan menstimulasi mereka untuk mengajukan bentuk pemecahan masalah yang dihadapi.

4) Guru menunjukkan contoh legenda.

5) Mengadakan tes tertulis

6) Penilaian hasil tes tertulis.

c. Pengamatan yaitu mengamati proses pembelajaran dan menilai hasil tes sehingga diketahui hasilnya. Atas dasar hasil tersebut digunakan untuk merencanakan tindak lanjut pada siklus berikutnya.

d. Refleksi yaitu merenungkan kembali hal-hal yang terjadi pada saat pelaksanaan hasil tindakan pada siklus I.

Adapun rancangan dari masing-masing siklus dalam penelitian tindakan kelas ini lebih jelasnya dijelaskan sebagai berikut:

Kondisi Awal: Kondisi awal diperoleh dengan melakukan wawancara dengan guru Bahasa Jawa SMP Negeri 8 Surakarta yaitu Sri Wurijani BA dengan menerapkan model pembelajaran kooperatif tipe NHT untuk meningkatkan aktifitas dan hasil belajar Bahasa Jawa Kompetensi Membaca Legenda Melalui Penerapan Model Pembelajaran Kooperatif Tipe NHT Bagi Siswa Kelas VIII E Semester 1 SMP Negeri 8 Surakarta Tahun Pelajaran 2015/2016? 
CENDEKIA, Vol. 11, No. 2, Oktober 2017

p ISSN: 1978 2098; e ISSN: 2407 8557

Http://cendekia.pusatbahasa.or.id; Email: cendekiaoslo@gmail.com

Center of Language and Culture Studies, Surakarta, Indonesia

Suprapti, Sri. 2017. Meningkatkan Hasil Belajar Membaca Legenda Melalui

Model Number Heads Together Siswa SMPN 8 Surakarta.

Cendekia, (2017), 11(2): 221 234.

\section{Rancangan Tindakan Siklus}

a. Perencanaan (planning), terdiri atas kegiatan:

1) penyusunan rencana pelaksanaan pembelajaran (RPP);

2) penyiapan skenario pembelajaran.

3) menyusun perangkat observasi untuk merekam segala kegiatan dalam proses pembelajaran.

4) Membuat perangkat penilaian dengan menerapkan sistem penilaian berbasis kelas.

b. Pelaksanaan (acting), terdiri atas kegiatan;

1) Guru mengarahkan siswa untuk bersama-sama menemukan cara yang tepat berbicara masalah legenda.

2) Siswa mulai berbicara legenda setelah memahami dan menguasai syaratsyarat berbicara legenda.

3) Guru bersama siswa merevisi legenda yang telah dibuat siswa.

4) Mengadakan penilaian tertulis, pemberian tugas.

c. Pengamatan (observing), yaitu mengamati proses pembelajaran dan menilai hasil tes serta hasil praktik sehingga diketahui hasilnya.

d. Refleksi (reflecting), yaitu merenungkan kembali hal-hal yang terjadi pada saat pelaksanaan hasil tindakan pada siklus II.

\section{Taknik Analisis Data}

Analisis data aktifitas belajar siswa, ada tiga data aktifitas belajar siswa yaitu aktifitas belajar siswa pada kondisi awal, siklus I dan siklus II dianalisis dengan menggunakan teknik deskriptif komparatif dilanjutkan refleksi. Data aktifitas belajar siswa pada kondisi awal dikomparasikan dengan data aktifitas belajar siswa pada siklus I kemudian dilakukan refleksi untuk menentukan tindakan pada siklus II. Kemudian membandingkan data aktifitas belajar siswa pada siklus I dengan data aktifitas belajar siswa pada siklus II,

Refleksi dat aktifitas belajar siswa, membuat simpulan data aktifitas belajar pada kondisi awal berdasarkan deskripsi komparatif kemudian memberikan ulasan atau simpulan tersebut guna menentukan tindakan untuk siklus berikutnya.

Analisis data hasil belajar siswa, ada tiga data hasil belajar siswa yaitu hasil belajar siswa pada kondisi awal, siklus I dan siklus II dianalisis dengan menggunakan teknik deskriptif komparatif dilanjutkan dengan refleksi.

\section{Prosedur Tindakan}

Secara rinci langkah-langkah dalam setiap siklus dijabarkan sebagai berikut : menyusun RPP sesuai dengan model pembelajaran yang akan digunakan, yaitu pembelajaran dengan model pembelajaran kooperatif NHT dengan penyajian materi. Menyusun lembar observasi pelaksanaan pembelajaran. Lembar observasi ini digunakan untuk menilai proses pembelajaran dan memantau aktifitas belajar siswa. Menyususn pedoman wawancara ini digunakan untuk menambah informasi tentang aktifitas siswa terhadap proses pelaksanaan pembelajaran dengan menggunakan model pembelajraan 
kooperatif NHT. Membuat dan memepersiapkan media pembelajaran. Media yang digunakan yaitu LKS. Menyusun soal tes. Tes tersebut diberikan pada akhir siklus.

\section{HASIL DAN BAHASAN}

\section{Deskripsi Data Aktifitas Belajar Bahasa Jawa}

Pada kondisi awal tersebut di atas menunjukkan bahwa aktifitas belajar siswa masih rendah, kepedulian siswa untuk terlibat dalam pembelajaran juga masih sangat kurang.

Tabel 1. Hasil observasi Aktifitas Belajar Siswa Pada Kondisi Awal

\begin{tabular}{|l|c|c|}
\hline \multicolumn{1}{|c|}{ Uraian Aktifitas Belajar } & Kondisi Awal & Persentase \\
\hline $\begin{array}{l}\text { Mendengarkan dan Memperhatikan penjelasan } \\
\text { guru }\end{array}$ & 14 & $43,75 \%$ \\
\hline Keberanian bertanya dan mengemukakan pendapat & 12 & $37,5 \%$ \\
\hline $\begin{array}{l}\text { Keberanian mempresentasikan hasil diskusi } \\
\text { kelompok di depan kelas }\end{array}$ & 4 & $12,5 \%$ \\
\hline
\end{tabular}

Nampak bahwa indikator-indikator aktifitas belajar siswa masih rendah dibawah indikator kinerja yang ingin dicapai masih kurang dari 75\%. Deskripsi Kondisi Awal Hasil Belajar Bahasa Jawa, sebelum mendapat tindakan secara rinci dapat dijelaskan pada tabel 2.

Tabel 2. Hasil belajar siswa pada Kondisi Awal sebelum dilakukan tindakan:

\begin{tabular}{|l|c|c|}
\hline \multicolumn{1}{|c|}{ Hasil Belajar } & Jumlah Siswa & Persentase \\
\hline Tidak Tuntas Belajar & 22 & $68,75 \%$ \\
\hline Tuntas Belajar & 10 & $31,25 \%$ \\
\hline Nilai Terendah & 55 & $62.5 \%$ \\
\hline Nilai Tertinggi & 90 & $0 \%$ \\
\hline Nilai Rata-Rata & 75 & $0 \%$ \\
\hline
\end{tabular}

\section{Deskripsi Pelaksanaan Tindakan Pada Siklus I}

Selama pelaksanaan tinakan siklus I siswa masih nampak banyak yang kurang aktif karena mungkin siswa baru mengenal model pembelajaran kooperatif tipe NHT baru. Hasil observasi/pengamatan aktifitas dan hasil belajar secara rinci dan jelas dapat dilihat pada tabel 3 . 
CENDEKIA, Vol. 11, No. 2, Oktober 2017

p ISSN: 1978 2098; e ISSN: 2407 8557

Http://cendekia.pusatbahasa.or.id; Email: cendekiaoslo@gmail.com

Center of Language and Culture Studies, Surakarta, Indonesia

Suprapti, Sri. 2017. Meningkatkan Hasil Belajar Membaca Legenda Melalui

Model Number Heads Together Siswa SMPN 8 Surakarta.

Cendekia, (2017), 11(2): 221 234.

Tabel 3. Hasil Observasi Aktifitas dan Hasil Belajar pada Kondisi Awal dan Siklus I

\begin{tabular}{|l|c|c|c|}
\hline \multicolumn{1}{|c|}{ Indikator Aktifitas Belajar } & $\begin{array}{c}\text { Kondisi } \\
\text { Awal }\end{array}$ & Siklus I & Keterangan \\
\hline $\begin{array}{l}\text { Mendengarkan dan Memperhatikan } \\
\text { penjelasan guru }\end{array}$ & $\begin{array}{c}14 \\
(43,75 \%)\end{array}$ & $\begin{array}{c}20 \\
(78,13 \%)\end{array}$ & $34,38 \%$ \\
\hline $\begin{array}{l}\text { Keberanian bertanya dan mengemukakan } \\
\text { pendapat }\end{array}$ & $\begin{array}{c}12 \\
(37,5 \%)\end{array}$ & $\begin{array}{c}22 \\
(68,75 \%)\end{array}$ & $31,25 \%$ \\
\hline $\begin{array}{l}\text { Keberanian mempresentasikan hasil } \\
\text { diskusi kelompok di epan kelas }\end{array}$ & $\begin{array}{c}4 \\
(12,5 \%)\end{array}$ & $\begin{array}{c}23 \\
(71,88 \%)\end{array}$ & $59,38 \%$ \\
\hline
\end{tabular}

\section{Deskripsi Pelaksanaan Tindakan Kelas Pada Siklus II}

Untuk mengatasi berbagai kekurangan peneliti mengambil keputusan: untuk meningkatkan kepercayaan diri pada siswa maka pada saat menyampaikan apersepsi guru tidak hanya mengenalkan materi tetapi meningatkan kembali materi tentang legenda. Guru memotivasi siswa dengan memberikan tambahan nilai kepada siswa yang aktif dalam pembelajaran. Guru menambah bimbingan kepada siswa ketika mengantarkan konsep baru dan ketika berdiskusi. Guru mempersiapkan diri sebelum pembelajaran dimulai sesuai dengan skenario RPP. Hasil pengamatan terhadap siswa diperoleh beberapa temuan sebagai berikut: (a). Suasana kelas sudah tertib, terkendali, dan kondusif karena siswa sudah terbiasa dengan kerja kelompok. (b). Keberanian siswa mulai tumbuh dengan adanya motivasi. (c). Penyajian hasil diskusi kelompok di depan kelas oleh wakil kelompok dapat berjalan dengan lancar.

Dari hasil pengamatan aktifitas belajar pada siklus dengan penerapan model Kooperatif tipe Numbered Heads Together perbandingan aktifitas belajar pada siklus I dan siklus II secara rinci dapat dilihat pada tabel 4.

Tabel 4. Perbandingan Hasil Observasi Aktifitas Belajar Pada Siklus I dan Siklus II

\begin{tabular}{|l|c|c|c|}
\hline \multicolumn{1}{|c|}{ Uraian Aktifitas } & Siklus I & Siklus II & Keterangan \\
\hline Mendengarkan dan Memperhatikan & 25 & 32 & Meningkat \\
penjelasan guru & $(78,13 \%)$ & $(100 \%)$ & $21,87 \%$ \\
\hline Keberanian bertanya dan & 22 & 32 & Meningkat \\
mengemukakan pendapat & $(68,75 \%)$ & $(100 \%)$ & $31,25 \%$ \\
\hline $\begin{array}{l}\text { Keberanian mempresentasikan hasil } \\
\text { diskusi kelompok di depan kelas }\end{array}$ & 23 & 32 & Meningkat \\
\hline
\end{tabular}

Berdasarkan hasil refleksi setelah tindakan pada siklus II maka peneliti dapat menyimpulkan bahwa hasil penelitian pada tindakan kelas siklus II telah berhasil meningkatkan aktifitas dan hasil belajar siswa. 
CENDEKIA, Vol. 11, No. 2, Oktober 2017

p ISSN: 1978 2098; e ISSN: 2407 8557

Http://cendekia.pusatbahasa.or.id; Email: cendekiaoslo@gmail.com

Center of Language and Culture Studies, Surakarta, Indonesia

Suprapti, Sri. 2017. Meningkatkan Hasil Belajar Membaca Legenda Melalui Model Number Heads Together Siswa SMPN 8 Surakarta.

Cendekia, (2017), 11(2): 221 234.

Tabel 5. Peningkatan Aktifitas Belajar Kondisi Awal sampai Kondisi Akhir Siklus II

\begin{tabular}{|l|c|c|c|}
\hline \multicolumn{1}{|c|}{ Indikator Aktifitas Belajar } & Prasiklus & Siklus I & Siklus II \\
\hline $\begin{array}{l}\text { Mendengarkan dan Memperhatikan } \\
\text { penjelasan guru }\end{array}$ & $\begin{array}{c}14 \\
(43,75 \%)\end{array}$ & $\begin{array}{c}25 \\
(78,13 \%)\end{array}$ & $\begin{array}{c}32 \\
(100 \%)\end{array}$ \\
\hline $\begin{array}{l}\text { Keberanian bertanya dan mengemukakan } \\
\text { pendapat }\end{array}$ & $\begin{array}{c}12 \\
(37,50 \%)\end{array}$ & $\begin{array}{c}22 \\
(68,75 \%)\end{array}$ & $\begin{array}{c}32 \\
(100 \%)\end{array}$ \\
\hline $\begin{array}{l}\text { Keberanian mempresentasikan hasil diskusi } \\
\text { kelompok di epan kelas }\end{array}$ & 4 & 23 & 32 \\
& $(12,50 \%)$ & $(71,88 \%)$ & $(100 \%)$ \\
\hline
\end{tabular}

\section{SIMPULAN}

Berdasarkan hasil penelitian yang telah dilaksanakan dalam dua siklus dengan menggunakan model pembelajaran kooperatif tipe NHT dapat meningkatkan aktifitas belajar bahasa Jawa pada membaca Legenda bagi siswa kelas VIII E SMP Negeri 8 Surakarta semester 1 Tahun Pelajaran 2015/2016. Hal tersebut nampak hasil pengamatan dari indikator: (a). Mendengarkan dan memperhatikan penjelasan guru, meningkat $21,87 \%$ dari $14(43,75 \%)$ dari kondisi awal $25(78,13 \%)$ menjadi $32(100 \%)$ pada kondisi akhir dari pasif ke sudah aktif mendengarkan dan mendengarkan. (b). Keberanian bertanya dan mengemukakan pendapat, meningkat $31,25 \%$ dari 12 $(37,50 \%)$ dari kondisi awal $22(68,75 \%)$ menjadi $32(100 \%)$ dari pasif tidak berani ke berani bertanya dan mengemukakan pendapat. (c). Keberanian mempresentasikan hasil diskusi kelompok di depan kelas meningkat 28,12\% dari $4(12,50 \%)$ dari kondisi awal $23(71,88 \%)$ menjadi $32(100 \%)$ dari pasif tidak berani mempresentasikan ke depan kelas menjadi berani maju ke depan kelas.

Hasil ini berimplikasi pada hal-hal berikut: (1). Meningkatkan hasil belajar Bahasa Jawa pada kompetensi membaca Legenda melalui penggunaan model pembelajaran kooperatif tipe NHT bagi siswa kelas VIII E SMP Negeri 8 Surakarta. (2). Meningkatkan aktifitas belajar siswa agar terlibat secara aktif dan kreatif dalam mengikuti proses pembelajaran di kelas melalui penggunaan model pembelajaran kooperatif Tipe NHT bagi siswa kelas VIII E SMP Negeri 8 Surakarta. (3). Dapat digunakan untuk tindak lanjut penelitian berikutnya dengan menggunakan model yang sama yaitu Tipe NHT yang dapat dikolaborasikan dengan model yang lain serta pada materi yang berbeda khususnya bagi peneliti sendiri juga bagi guru lainnya.

\section{DAFTAR PUSTAKA}

Ahmadi, Supriyono. 2006. Psikologi Pendidikan. Jakarta: Rineka Cipta.

Dimyati dan Mudjiono. 2004. Belajar Dan Pembelajaran. Jakarta: Depdikbud Dirjen Dikti.

Purwodarminto WJS. 2000. Kamus Besar Bahasa Indonesia, Jakarta BP. Suprijono. 2009. Cooperative Learning. Yogyakarta : Pustaka Pelajar. Suharsini Arikunto. 2003. Penilaian Laporan PTK. Jakarta : Rineka Cipta. Sugiyanto. 2008. Model-model Pembelajaran Inovatif. Surakarta : PSG Winkel. W.S. 2007. Psikologi Pengajaran. Jakarta : Gramedia 
CENDEKIA, Vol. 11, No. 2, Oktober 2017

p ISSN: 1978 2098; e ISSN: 2407 8557

Http://cendekia.pusatbahasa.or.id; Email: cendekiaoslo@gmail.com

Center of Language and Culture Studies, Surakarta, Indonesia

Suprapti, Sri. 2017. Meningkatkan Hasil Belajar Membaca Legenda Melalui Model Number Heads Together Siswa SMPN 8 Surakarta.

Cendekia, (2017), 11(2): 221 234. 